\title{
Effects of bilingualism on inhibitory control and working memory: A study with early and late bilinguals
}

\author{
Rossana Kramer \\ Mailce Borges Motab
}

\begin{abstract}
A dense body of research shows that cognitive functions change with age. More recently, studies have provided evidence that bilingualism aids in offsetting agerelated losses in executive function (Bialystok, Craik, Klein $\mathcal{E}$ Viswanathan, 2004; Salvatierra, 2010). The present study investigates the performances of early bilinguals (Brazilian Portuguese/Hunsrückisch), late bilinguals (Brazilian Portuguese/English), and monolinguals (Brazilian Portuguese) on executive control and working memory tasks. Participants $(N=$ 104) performed an executive control task (Simon) and a working memory (Alpha Span) task. Statistical analyses showed significant age-related effects on executive functions: younger adults outperformed older adults in the tasks. Furthermore, early bilinguals presented more efficient inhibitory processes showing smaller Simon effect costs and higher working memory span than monolinguals. As for the late bilingual group, their performance on inhibitory control tasks was significantly faster than that of their peer monolingual group. Results suggest that bilingualism, regardless of the context and age of acquisition, has an effect on inhibitory control and working memory.
\end{abstract}

Keywords: bilingualism, aging, inhibitory control, working memory

a PUC-RS - Pontifícia Universidade Católica do Rio Grande do Sul. Doutoranda no Programa de PósGraduação em Letras na PUC-RS. rossanakramer@yahoo.com.br

${ }^{\mathrm{b}}$ UFSC - Universidade Federal de Santa Catarina. Departamento de Língua e Literatura Estrangeiras. mailce@cce.ufsc.br 


\section{Introduction}

To use our central cognitive abilities-attention, perception, thinking, planning, reasoning, memory, language, and decision making (Reed, 2007)-human beings must expend considerable mental effort. In fact, a number of cognitive functions decline during the aging process (BIALYSTOK; CRAIK, 2006; HOFER; ALWIN, 2008; PARK; SCHWARZ, 2000), which according to Buckner, Head, and Lustig (2006), begins as early as the age of 30. As Buckner et al. (2006) state, decline because of normal brain aging can affect the executive functions that involve several processes, for example, planning, decision making, inhibition of irrelevant information, coordination and monitoring of information, cognitive flexibility in problem solving, and regulation of behavior (CRAIK; SALTHOUSE, 2000; DANIELS; TOTH; JACOBY, 2006; LUSZCZ; LANE, 2008).

Luszcz \& Lane (2008) define executive functions as including three executive control processes for cognition: a) processes that draw on working memory, such as monitoring and coordination; $b$ ) processes that require selective attention, such as inhibiting inappropriate responding; and c) processes that draw on divided attention, such as switching between different tasks or sources.

This study addresses two of the processes influenced by normal aging: inhibitory control and working memory. Inhibitory control is the ability to focus on relevant cues by suppressing irrelevant information or stimuli while performing any day-to-day task that involves attentional control (MIYAKE et al., 2000). Age-related differences reveal that older adults perform poorer than younger participants on tasks or in situations that require inhibition. Park (2000) explains that as we age, we have more trouble concentrating on only one item. That is, we easily fail to inhibit distractions or conflicts. Difficulty in attending to a goal and in quickly inhibiting competing stimuli begins to affect many everyday activities.

Working memory contributes to comprehending what we read and speak; it is essential for mental calculation and problem solving, reasoning, and planning (CONWAY et al., 2008). Not surprisingly, however, according to Conway et al. (2008), is that the ability to maintain and process information depends on the working memory capacity of each individual. 
Even with individual differences, Park et al. (2002) well documented that the ability to maintain information active for processing in working memory begins to decline in our 20 s, and that this ability gradually declines across the lifespan. As we age, we have greater difficulty holding, manipulating, and dealing with incoming information, particularly if the task involves performing all these processes simultaneously.

Valenzuela (2008) explains that many factors contributing to cognitive decline are biological. However, there is strong evidence that some environmental factors, also known as lifestyle factors, can help preserve cognitive functioning in elderly individuals (BIALYSTOK; CRAIK; FREEDMAN, 2007; VALENZUELA, 2008). As Valenzuela (2008) observes, complex mental activities that promote mental stimulation contribute to cognitive maintenance; thus, education and occupational status may help lessen cognitive decline. Recent studies on the relationship between bilingualism and aging have found that bilingualism can be considered a complex mental activity, and that age-related cognitive losses in executive control may be attenuated by bilingualism across the lifespan (BIALYSTOK et al., 2004; BIALYSTOK; , MARTIN; VISWANATHAN, 2005; BIALYSTOK et al., 2007).

Various researchers(BIALYSTOKET AL., 2004; BIALYSTOK ET AL., 2005; BIALYSTOK ET AL., 2007; BIALYSTOK; CRAIK; LUK, 2008; BIALYSTOK, 2010; SALVATIERRA, 2007; SALVATIERRA; ROSSELLI, 2010) have conducted studies that postulate early bilingualism as providing benefits to cognitive functions, mainly executive control functions. Evidence of enhanced executive control was found in bilingual children and adults (BIALYSTOK et al., 2004; BIALYSTOK et al., 2005) and has been taken as an indication that managing two languages throughout the lifespan enhances the development of executive control functions. In other words, lifelong bilingualism may offset the effects of aging on cognitive processing, particularly that of inhibitory functioning. In the light of this finding, the present study not only investigates the benefits of lifelong bilingualism in early bilinguals, as observed by Bialystok et al. $(2004,2005)$, but also aims to verify whether this same cognitive advantage exists in bilinguals who have acquired a second language through formal instruction. 


\section{Method}

\subsection{Participants}

For this study, we recruited 104 participants selected in three cities in the state of Santa Catarina, Brazil. Their ages ranged from 18 to 84 years. The participants consisted of early bilinguals (Brazilian Portuguese/Hunsrückisch), late bilinguals (Brazilian Portuguese/English), and their monolingual peers (Brazilian Portuguese). All participants were right-handed.

With regard to the early bilinguals, German immigrants brought the dialect Hunsrückisch to Brazil from the Hunsrück region of Germany in the 1830s (BRAUN, 2010). Hunsrückisch, recognized as a Brazilian immaterial cultural patrimony, is spoken in the west of Santa Catarina and Paraná, and in northwestern Rio Grande do Sul. Most people who live in these regions of Brazil have been bilingual since childhood and have used two languages regularly for most of their lives (ALTENHOFEN; FREY, 2006). The language background questionnaires for this study indicated that Hunsrückisch was the first language the early bilingual participants learned, followed by Portuguese. With one exception, all the early bilinguals reported beginning to learn Portuguese in school at the age of five or six; the exception reported having his first contact with Portuguese at the age of eight. All early bilinguals were actively using both languages at the time of the study.

As for the late bilinguals, the language background questionnaire (explained below) indicated that the late bilinguals had lived in an English-speaking country for at least two months within the past two years. Furthermore, the late bilinguals reported that they began learning English as a second language when they were about 12 years old through classroom instruction. In addition, all the late bilinguals completed a proficiency test, detailed below, that measured their English language abilities.

The early bilingual group consisted of: 10 younger adult bilinguals, aged $18-26$ years (mean age, 22.6 years) with a mean of 13.4 years of schooling; 14 middle adult bilinguals, aged $30-54$ years (mean age, 43.5 years) with a mean of 12.8 years of schooling; and 14 older adult bilinguals, aged 65-84 years (mean 
age, 72 years) with a mean of 5.3 years of schooling. Their 38 monolingual peers consisted of 10 younger adult monolinguals, aged 18-26 years (mean age, 20.6 years) with a mean of 13 years of schooling; 14 middle adult monolinguals, aged $30-54$ years (mean age, 46 years) with a mean of 9.9 years of schooling; and 14 older adult monolinguals, aged 65-84 years (mean age, 72.6 years) with a mean of 5.6 years of schooling. All the participants mentioned above were recruited in the countryside.

The late bilingual group consisted of 14 younger adults, aged 18-26 (mean ages, 22.5 years) with means of 14.4 of schooling. Their monolingual peers consisted of 14 younger adults matched for age (mean ages, 20.7 years) with 12.6 years of schooling. These participants were all recruited in a capital city and were regular students at a major federal university where, at the time of the data collection, late bilinguals were attending English classes in advanced groups. These late bilinguals had learned their second language through instruction in classroom settings.

In all, the participants comprised eight different groups. There were four groups of bilinguals. Three groups were early bilingual, Brazilian Portuguese/Hunsrückisch speakers, divided according to age group: younger adults (18-26), middle adults (30-54), and older adults (65-84). The fourth bilingual group consisted of the late bilinguals, Brazilian Portuguese/ English speakers. The monolingual Brazilian Portuguese speakers were divided into three groups corresponding to the early bilingual Brazilian Portuguese/Hunsrückisch speakers, that is, according to age group. The fourth monolingual group was age-group and educational peers of the late bilinguals.

Besides being matched for age, within groups, the participants were matched for gender. All the participants signed a consent form agreeing to participate voluntarily in this research. The data was collected in two quiet, well lit rooms. The general procedures consisted of all 104 participants completing a language background and a general background questionnaire, and then two screening tests: the Mini-Mental State Examination (MMSE) and the Beck Depression Inventory (BDI). These questionnaires and screening tests were designed and administered in Portuguese. After the questionnaires and screening tests, the participants were asked to perform the cognitive tasks. 


\subsection{Assessing participants}

The above mentioned language background questionnaire consisted of questions regarding language use, for instance, which language participants use in different contexts, such as at home or at work. The background questionnaire collected general information about the participants, including information about their handedness.

Of the two screening tests, the first was the MMSE (FOLSTEIN et al., 1975), which contains simple questions related to various areas such as arithmetic, repetition of words, and motor skills. The test detects whether individuals have some sort of cognitive impairment. BERTOLUCCI etal. (1994) first validated the MMSE for administration to the Brazilian population. The second screening test, the BDI (BECK et al., 1993), consists of questions to determine symptoms of depression. This screening test was translated and adapted to the Brazilian population by Gorestein and Andrade (1996). The BDI consists of 21 questions about how the participant had been feeling during the past week. Mendonça (2006) explains that although the MMSE and the BDI are clinical tests, both have frequently been used in cognitive research conducted with adults and older adults. Thus, both screenings were administered to the present study's participants because any symptoms of cognitive impairment or depression were likely to influence their performance on the tasks, and thus the study results.

An English proficiency test was administered to all of the Portuguese/English late bilinguals. The test was developed based on the design and questions on the Educational Testing Service (ETS) website (http://www.ets.org/toefl) as a short, paper-based form of its Test of English as a Foreign Language (TOEFL). For this research, the test was divided into four sections: listening comprehension, structure and written expression, reading comprehension, and writing. The three early bilingual groups (Hunsrückisch speakers) were not formally tested. However, to guarantee effective communication, two speakers of Hunsrückisch from the west of Santa Catarina helped recruit fluent Hunsrückisch speakers. The participants who had similar background and scored well in the screening tests and the proficiency test, in the case of late bilinguals, were invited to perform the tasks. 


\subsection{Inhibitory control and working memory tasks}

In this study, two cognitive tasks were used: the Simon task assessed inhibitory control, and the Alpha Span task assessed verbal working memory. Both tasks were run on a Dell laptop, 14 inches and connected to a 15-inch Dell monitor for stimulus display. The Simon task was designed and run using the software E-Prime 2.0; the Alpha Span task was presented in PowerPoint. In addition, a response box (SRBOX) was used to increase accuracy in measuring participants' response times on the Simon task. The two tasks described below were presented to participants in a random order. There were practice trials for all the tasks, and the participants could clarify doubts about the tasks before the experiment.

The Simon task 2 Colors, In the Simon task designed for the present study, participants were to press the SRBOX left or right shift key according to the color appearing on the screen. For example, when participants saw a blue square, they were to press the shift key on their left (Key 1); when they saw a yellow square, they were to press the shift key on their right (Key 5). There were congruent trials, that is, the correct key was on the same side as the stimulus, and incongruent trials, that is, the correct key was on the opposite side of the stimulus. The difference between reaction times to congruent and incongruent items is called the Simon effect, which indicates the efficiency of inhibitory control. Participants have to focus their attention on the color, but ignore the side where a stimulus appears. In the 2 Color test, after the blue or yellow stimulus appeared, it remained on the screen until the participant responded, following the same pattern of other studies using the Simon task (Bialystok et al., 2004; Bialystok, 2006). Participants' reaction times (RT) and accuracy (ACC) for each stimulus were recorded.

The Alpha Span task Developed in English by Fergus Craik in 1986, the Alpha Span task is considered complex and was included here as a measure of working memory. The present researchers created a Portuguese version on the basis of the original sent by Craik (personal communication, March 2010). To do so, we made an effort to select the words most frequently used in Brazilian Portuguese. Words of only one and two 
syllables were chosen. In the Alpha Span task designed for this study, 70 words were arranged into 14 lists. The experiment began with two lists consisting of two words each, then two lists of three words each, followed by two lists of four words each. The number of words on the lists increased gradually to eight. The words on each list were presented to participants one word at a time in a randomized order (e.g., lei, time, rua) both read aloud by the researchers and displayed on the screen, simultaneously. The participants were asked to recall the words and repeat them in alphabetical order (e.g., lei, rua, time). Each word remained on the screen for approximately $1000 \mathrm{~ms}$. After presenting each list of words, the experimenter took note of the words the participants could repeat in the alphabetical sequence in an answer sheet. The score was determined as follows: (a) if the participant remembered all the words and repeated them in the correct alphabetical order, $\mathrm{s} /$ he was given 1 point for each word. For example, in the list "voto, pai, loja, meia" if the recall was correct (loja, meia, pai, voto), the score was 4 (1 point for each word); (b) For a partially correct sequence (e.g., loja, meia, ?, voto), the participant would score 1 point for loja, 1 point for meia, and 0 for voto. The total score here would be 2 because the participant only scores for correct adjacent runs. However, if the sequence remembered was "loja, meia, pai, ?", the score would be 3 points, since the 3 words are adjacent. The presentation of the lists stopped two levels beyond the participant's last span. For example, if the participant recalled all the words in the alphabetical sequence at level 5 , but not at level 6, the experiment proceeded until level 7 and would stop at this level if the participant failed both trials/lists.

\subsection{Statistical procedures}

An analysis of variance (ANOVA) procedure was used to determine whether there were significant differences among the eight groups (104 participants). For the Simon task 2 Colors, the one-way ANOVA was adopted to examine differences among the eight groups' performances. For this task, the variables were the groups as the independent variable and reaction time (RT), RT congruent, RT incongruent, and the 
Simon effect as dependent variables, analyzed separately. Then, the performances of the early and late bilinguals were analyzed separately. The early bilingual groups and their monolingual counterparts were compared using a two-way ANOVA. The variables were age group (younger adult, middle adult, and older adult) and language group (bilinguals and monolinguals) as independent variables. The dependent variables were RT, RT congruent, RT incongruent, and the Simon effect, and were also analyzed separately. A t-test was run to examine late bilinguals' and monolinguals' performance on the Simon task 2 Colors. The dependent variables were RT, RT congruent, RT incongruent, and the Simon effect; however, the independent variable was the two language groups. For the Alpha Span task, the dependent variable was always the score obtained by the participants. One-way ANOVA was conducted with the eight groups first, followed by a two-way ANOVA for early bilinguals and monolinguals, in which the independent variables were age group and language group. Finally, a $t$-test was applied to verify the late bilingual group's performance compared to that of their peer monolingual group. Whenever a significant difference was detected by the ANOVA, a posthoc test was run to determine where this difference was. For all analyses, the alpha was set at the $<.05$ level.

\section{Results}

3.1 Early bilinguals and their monolingual peers

As shown in Table 1, the mean reaction times of the early bilinguals and their monolingual counterparts in the Simon task 2 Colors were very similar within age groups: the younger adult bilinguals and monolinguals' performances do not differ much in overall reaction time ( $450.07 \mathrm{~ms}$ and 452.66 $\mathrm{ms}$, respectively). The main reaction times of middle adult monolinguals and bilinguals are similar as well $(525.64 \mathrm{~ms}$ and $524.35 \mathrm{~ms}$, respectively). Only in older adult participants a small difference in means can be observed: the older monolingual group's response time $(650.56 \mathrm{~ms})$ was lower than the older bilingual group's reaction time $(726.69 \mathrm{~ms})$ in the Simon task 2 Colors. 
Table 1

Descriptive Statistics for Simon Task 2 Colors - Mean Reaction Time and Accuracy by age and language group (Early bilinguals)

\begin{tabular}{|c|c|c|c|c|c|c|c|c|}
\hline \multirow[b]{2}{*}{ Age and language groups } & \multirow[b]{2}{*}{$\mathrm{N}$} & \multirow[b]{2}{*}{$\begin{array}{c}\mathrm{RT} \\
\text { (in } \mathrm{ms} \text { ) }\end{array}$} & \multirow[b]{2}{*}{$\begin{array}{c}\text { A ccuracy } \\
(\%)\end{array}$} & \multicolumn{2}{|c|}{ Congruent } & \multicolumn{2}{|c|}{ Incongruent } & \multirow[b]{2}{*}{ Simon effect } \\
\hline & & & & $\begin{array}{c}\text { RT } \\
\text { (in ms) }\end{array}$ & $\begin{array}{c}\text { Accuracy } \\
(\%)\end{array}$ & $\begin{array}{c}\mathrm{RT} \\
\text { (in ms) }\end{array}$ & $\begin{array}{c}\text { Accuracy } \\
(\%)\end{array}$ & \\
\hline \multicolumn{9}{|l|}{ Younger } \\
\hline Monolinguals & 10 & $452,66(72.32)$ & 96.56 & $435,11(77.91)$ & 98.75 & $470,21(75.72)$ & 94.37 & $51,85(28.87)$ \\
\hline Bilinguals BP/H & 10 & $450,07(40.02)$ & 96.56 & $435,12(49.91)$ & 97.5 & $464,99(49.66)$ & 95.62 & $29,87(59.15)$ \\
\hline \multicolumn{9}{|l|}{ Adult } \\
\hline Monolinguals & 14 & $525,64(78.59)$ & 96.87 & $511,2(87.14)$ & 97.77 & $540,08(79.45)$ & 95.98 & $28,87(55.74)$ \\
\hline Bilinguals BP/H & 14 & $524,35(74.15)$ & 98.21 & $507,75(69.58)$ & 98.66 & $540,95(87.37)$ & 97.76 & $33.19(54.37)$ \\
\hline \multicolumn{9}{|l|}{ Older } \\
\hline Monolinguals & 14 & $650,56(123.72)$ & 94.64 & $600,3(124.63)$ & 96.88 & $700,79(134.18)$ & 92.41 & $100,49(76.61)$ \\
\hline Bilinguals BP/H & 14 & $726,69(233.56)$ & 97.31 & $697,68(194.07)$ & 98.66 & $755,71(286.38)$ & 95.98 & $58,03(145.46)$ \\
\hline
\end{tabular}

For the Simon task 2 Colors, a significant difference $(F(2$, $70)=22.813, p<0.0001)$ was found for age group but not for language group in regards to the RT data $(F(1,70)=.671, p=$ .415). As expected, the reaction times of the older adult groupsboth the early bilinguals and monolinguals-were greater than those of the younger adult and middle adult groups. The younger adult groups-both the early bilinguals and monolinguals - were faster than the bilingual and monolingual middle adult and older adult groups for congruent trials $(F(2$, $70)=21.768, p<0.0001)$. For incongruent trials, the younger adult and middle adult groups, early bilinguals and their monolingual peers were faster than the two older adult early bilingual and monolingual groups: for the older adult groups, $F(2,70)=20.327, p<0.0001$. The Simon effect result was not statistically significant among the six groups, $F(2,70)=2.891$, $p=.62$. The results so far reveal no statistically significant language group differences between the performances of early bilinguals and their monolingual counterparts on the Simon task 2 Colors. In other words, monolinguals were as fast as early bilinguals in inhibitory control. Furthermore, the results show no statistically significant difference among these groups in accuracy. Although the Portuguese/Hunsrückisch bilinguals were, in general, more accurate than their monolingual peers on both congruent and incongruent trials, statistically, the accuracy was as great for monolinguals as it was for bilinguals. 
The results for early bilinguals and their monolingual peers on the Alpha Span task are reported in Table 2. The adult groups, early bilinguals and monolinguals, performed better than the middle adult and older adult groups on the Alpha Span task $(F(2,70)=30.404, p<0.0001)$.

Table 2

Descriptive Statistics for Alpha Span Task - Mean measures by age and language group (Early bilinguals)

\begin{tabular}{lccc}
\hline Age and language groups & N & Mean & SD \\
\hline Younger & & & 10.3 \\
$\quad$ Monolinguals & 10 & 25.8 & 5.6 \\
$\quad$ Bilinguals BP/H & 10 & 28.7 & 9.6 \\
Adult & & & 5 \\
$\quad$ Monolinguals & 14 & 18.9 & \\
$\quad$ Bilinguals BP/H & 14 & 22.4 & 7 \\
Older & & & 8.3 \\
$\quad$ Monolinguals & 14 & 8.5 & 11 \\
Bilinguals BP/H & 14 & 11 & \\
\hline
\end{tabular}

Note. $\mathrm{N}$ = number of participants; $\mathrm{BP} / \mathrm{H}=\mathrm{B}$ razili an Portuguese/Hunsrückisch; $\mathrm{SD}=$ Standard Deviations

As Table 2 shows, the monolinguals scored lower in the Alpha Span task than the early bilinguals. Younger adult, middle adult, and older adult monolinguals' mean scores were $\mathrm{M}=25.8, \mathrm{M}=18.9$, and $\mathrm{M}=8.5$, respectively; younger adult, middle adult, and older adult bilinguals' mean scores were $\mathrm{M}=28.7, \mathrm{M}=22.4$, and $\mathrm{M}=11$, respectively. Although bilinguals have higher scores than their monolingual peers, statistically, the scores were as great for bilinguals as they were for monolinguals $(F(1,70)=2.659, p=.107)$.

3.2 Late bilinguals and their monolingual peers

Table 3 presents the late bilinguals and their monolingual peers' results in the Simon task 2 Colors. A $t$-test conducted with the late bilinguals and their monolingual peers shows no significant differences between their overall RTs: $t(26)=1.511, p$ $=.143$. However, a significant difference between the RT means for late bilinguals and their monolingual peers was found for incongruent data. A t-test confirmed that late bilinguals were significantly faster than their monolingual counterparts on incongruent trials, $t(26)=2.45, p=.021$. 
Table 3

Descriptive Statistics for Simon Task 2 Colors - Mean RT and Accuracy by language group (Late bilinguals)

\begin{tabular}{|c|c|c|c|c|c|c|c|c|}
\hline \multirow[b]{2}{*}{ Language groups } & \multirow[b]{2}{*}{$\mathrm{N}$} & \multirow[b]{2}{*}{$\begin{array}{c}\text { RT } \\
\text { (in ms) }\end{array}$} & \multirow[b]{2}{*}{$\begin{array}{c}\text { Accuracy } \\
(\%)\end{array}$} & \multicolumn{2}{|c|}{ Congruent } & \multicolumn{2}{|c|}{ Incongruent } & \multirow[b]{2}{*}{ Simon effect } \\
\hline & & & & $\begin{array}{c}\text { RT } \\
\text { (in ms) }\end{array}$ & $\begin{array}{c}\text { Accuracy } \\
(\%)\end{array}$ & $\begin{array}{c}\text { RT } \\
\text { (in ms) }\end{array}$ & $\begin{array}{c}\text { Accuracy } \\
(\%)\end{array}$ & \\
\hline Monolinguals & 14 & $486,8(103.1)$ & 98.6 & $471,8(130.5)$ & 99.1 & $512(93.7)$ & 98.2 & $40,18(81.64)$ \\
\hline Bilinguals $\mathrm{BP} / \mathrm{E}$ & 14 & $433,1(83.7)$ & 97.1 & $435,2(3.2)$ & 97.7 & $431(80.7)$ & 96.4 & $-4,18(48.88)$ \\
\hline
\end{tabular}

Note. Standard deviations (SD) are in parentheses; $\mathrm{N}=$ number of participants; $\mathrm{RT}=$ Reaction Time; $\mathrm{BP} / \mathrm{E}=\mathrm{Brazilian}$ Portuguese/English; ms $=$ milliseconds

Table 4 displays the results of late bilinguals and monolinguals' performances on the Alpha Span task: Late bilinguals scored higher than monolinguals $(\mathrm{M}=32.14$ and $\mathrm{M}=$ 27.93, respectively). However, the difference was not statistically significant $(t(26)=-1.254, p=0.221)$.

Table 4

Descriptive Statistics for Alpha Span Task - Mean measures by language group (Late bilinguals)

\begin{tabular}{llll}
\hline Language groups & $\mathrm{N}$ & Mean & SD \\
\hline Monolinguals & 14 & 27.93 & 8.9 \\
Bilinguals PB/E & 14 & 32.14 & 8.8 \\
\hline
\end{tabular}

Note. $\mathrm{N}$ = number of participants; BP/E = Brazilian Portuguese/English; SD = Standard Deviations

\section{Discussion}

Aging is associated with cognitive decline that affects executive control and memory (BUCKNER et al., 2006). However, Bialystok and colleagues (2004) have recently provided evidence that bilingualism may attenuate age-related losses in executive function. To verify the effects of aging on cognitive processes and whether bilingualism can help offset aging effects on executive function, two cognitive tasks were administered to monolinguals and early bilinguals: an inhibition control task (Simon task 2 Colors) and a verbal working memory task (Alpha Span task). On the basis of compelling evidence that early bilingualism enhances cognitive abilities in executive functions, this investigation also attempted to verify whether bilinguals who had learned a second language in a formal context would show positive effects in executive functions. 
1 http://www.ibge.gov. br/home/presidencia/ noticias_visualiza. php?id_noticia=1717\&id_ pagina $=1$
The two tasks mentioned above were also administered to a younger adult group of late bilinguals (Brazilian-Portuguese/ English speakers) to verify whether the advantages reported by Bialystok et al. (2004) can also be observed in those who acquire a second language through formal instruction.

In contrast to what Bialystok et al. (2004) postulated, the present study found no statistically significant advantages for early bilinguals in reaction time in congruent and incongruent trials in the Simon task 2 Colors. These results are similar to those reported by Billig (2009) and Pinto (2009), who also investigated early bilingualism with a Hunsrückisch/ Portuguese population. Billig (2009) concluded that, perhaps, other factors in addition to bilingualism, such as schooling, contribute to the cognitive advantage that early bilinguals show in inhibitory control task. According to Valenzuela (2008), formal education level is a predictor of cognitive maintenance. Bialystok and colleagues have reported that their older participants had a bachelor's degree (BIALYSTOK ET AL., 2004) or even more years of education than their younger participants (BIALYSTOK ET AL., 2008). The level of formal education in Brazil is considered low, particularly in the older population. In Brazil, according to the Instituto Brasileiro de Geografia e Estatistica (IBGE - Brazilian Institute for Geography and Statistic), $46.2 \%$ of the population over 60 years old is illiterate. ${ }^{1}$ In the present study, the older groups, both early bilinguals and monolinguals, reported only 5.3 and 5.6 years of formal education, respectively. In Bialystok's studies (e.g., BIALYSTOK ET AL., 2004; 2008), the older participants reported having higher education, corresponding to about 15 years of formal education. Speculatively, it can be argued that a bilingual advantage may be greater in populations with a higher level of formal education.

Furthermore, some tasks require more selective attention and ability to inhibit misleading information than others. The Simon task applied here presented congruent and incongruent trials at random; this demands much attention by the participants. According to Bialystok et al. (2005), misleading information is more demanding than relevant information ecause participants depend heavily on inhibitory mechanisms to choose the correct response. As mentioned 
above, the difference between the time taken to react to congruent and incongruent information is the Simon effect, which indicates the efficiency of inhibitory control. In the Simon task 2 Colors, there are two stimuli: color and position. Participants have to focus their attention on the color, but ignore the side where a stimulus appears. Although the result for the Simon effect was not statistically significant among the eight groups $(F(7,96)=1.970, p=0.067)$, there were trends towards significance. The results show that the older adult bilingual group took less reaction time, i.e., a smaller Simon effect $(58.03 \mathrm{~ms})$ than the older monolingual group (100.49 $\mathrm{ms})$. In other words, the older bilingual group suffered less interruption from the incongruent items, indicating a higher level of inhibitory control in older adult bilinguals than in older adult monolinguals. Furthermore, the early bilingual groups were more accurate than their monolingual peer groups on incongruent trials, indicating that the bilinguals could better inhibit misleading cues.

As mentioned above, the level of formal education helps to predict cognitive maintenance. However, since this study found no statistically significant bilingual advantage, another factor worth exploring is language dominance, that is, the dominance of each language in four abilities: speaking, writing, listening, and reading comprehension. The bilinguals studied by Bialystok et al. (2004) were formally educated in their two languages. In the present study, the early bilinguals did not have formal access to Hunsrückisch, that is, they did not read and write in Hunsrückisch. Therefore, because of the difference in the degree of dominance, early bilingualism's effects on inhibitory control might be influenced not only by the context of language use, including frequency and social context (PARADIS, 2004), but also by speaking, writing, listening, and reading-comprehension abilities. Speculatively, it can be argued that early bilingualism's positive effects on inhibitory control may partially depend on the levels of dominance in the two languages. In this case, the level of dominance relates to the level of formal education.

In the late bilingual group, significant differences were found in reaction times on congruent and incongruent trials. Incongruent items tend to elicit slower responses than 
congruent items (BIALYSTOK et al., 2005), and thus higher reaction times than for congruent items. Surprisingly, however, in this study, the late bilingual group was faster on incongruent trials, suggesting less inhibition cost. This result seems to indicate that the beneficial effects of bilingualism on executive control and inhibitory processing may also be present in those who have learned a second language in the classroom context.

Furthermore, the late bilingual group used Portuguese for schooling and social life, so English is not their dominant language. Possibly, greater inhibitory control is required when late bilinguals perform in their second, less dominant language. Speculatively, it could be posited that inhibitory processes are involved to inhibit the dominant language (in this case, Portuguese). In other words, to perform in their second language, late bilinguals must focus on relevant linguistic representations and ignore linguistic representations from their dominant language. In the present study, the results indicate that late bilingualism may help the development of inhibitory control mechanisms (COSTA; HERNÁNDEZ; SEBASTIAN-GALLÉS, 2008). On the other hand, the early bilingual groups who encountered no language dominance by Brazilian Portuguese exercised this ability less.

The present study shows a statistically significant difference among age groups in RT means for the Simon task 2 Colors. Results demonstrated that the older adult monolingual and early bilingual groups performed significantly more slowly on congruent and incongruent trials as compared to the younger monolingual and early bilinguals groups. This difference reinforces previous evidence that the ability to control attention and inhibit irrelevant information decreases as age increases (SALTHOUSE; MEINZ, 1995; ALAIN; WOODS, 1999; ZELLNER; BÄUML, 2006; BUTLER; ZACKS, 2006). The present study corroborates Bialystok et al. $(2004,2008)$ who reported that regardless of language (monolingual or bilingual), older adult monolinguals and bilinguals show significant disadvantage when compared to their younger peers. In these two studies, older adult groups were slower on tasks that required speed and inhibition, consistent with the notion that reaction time increases with age (VAN DER LUBBE; VERLEGER, 2002). Furthermore, in the present study results show that the 
magnitude of the Simon effect increases with age; this may be interpreted as evidence that older adults' ability to inhibit misleading cues decreases with age (BIALYSTOK et al., 2004).

Although for late bilinguals, the Simon effect was not statistically significant, a comparison shows that late bilinguals significantly outperformed monolinguals on incongruent trials in the Simon task 2 Colors $(\mathrm{t}(26)=2.45, p=0.021)$. These results indicate that late bilinguals are less distracted by interference on irrelevant trials than monolinguals. According to Costa et al. (2008), who investigated the relationship between early bilingualism and executive control functions, dealing with two linguistic representations requires control. In other words, bilinguals need to focus on the relevant language and ignore the other. For this reason, bilinguals are expected to perform better on non-congruent trials. In this study, the mean RTs were lower for late bilinguals than for their monolingual peers. These findings may indicate that becoming fluent in a second language late in life can also bring positive cognitive benefits. In summary, late bilinguals in the present study were better able to inhibit irrelevant items than monolinguals. Late bilingualism seems to contribute to the enhancement of executive control functions in nonverbal cognitive tasks that involve inhibitory control.

The Alpha Span task is considered complex and was included here as a measure of working memory capacity. Considering that working memory stores and manipulates a limited amount of information, and that processing slows with age, it was expected that the older adult groups would score lower than the younger adult and the middle adult groups. The present study reveals statistically significant age-related differences in that the older adult bilinguals and monolinguals recalled fewer words than their younger adult and middle adult counterparts.

Since working memory tasks involve high cognitive processing demands and executive control functions, finding language group differences in the Alpha Span task was expected. Performing this particular span task requires not only storage and manipulation of items but also the ability to inhibit the words presented in previous lists and focus on the current list. Engle (2002) explains that attentional 
control influences working memory capacity, and that performing working memory tasks requires attention for storing information while ignoring irrelevant items. As a result, bilinguals would be expected to perform better than monolinguals on the Alpha Span task, and Figure 1 shows confirmation in that all bilinguals-early and late-obtained better scores than their monolingual peers.

Figure 1 - Early and late bilinguals and their monolingual peers' performance on the Alpha Span task.

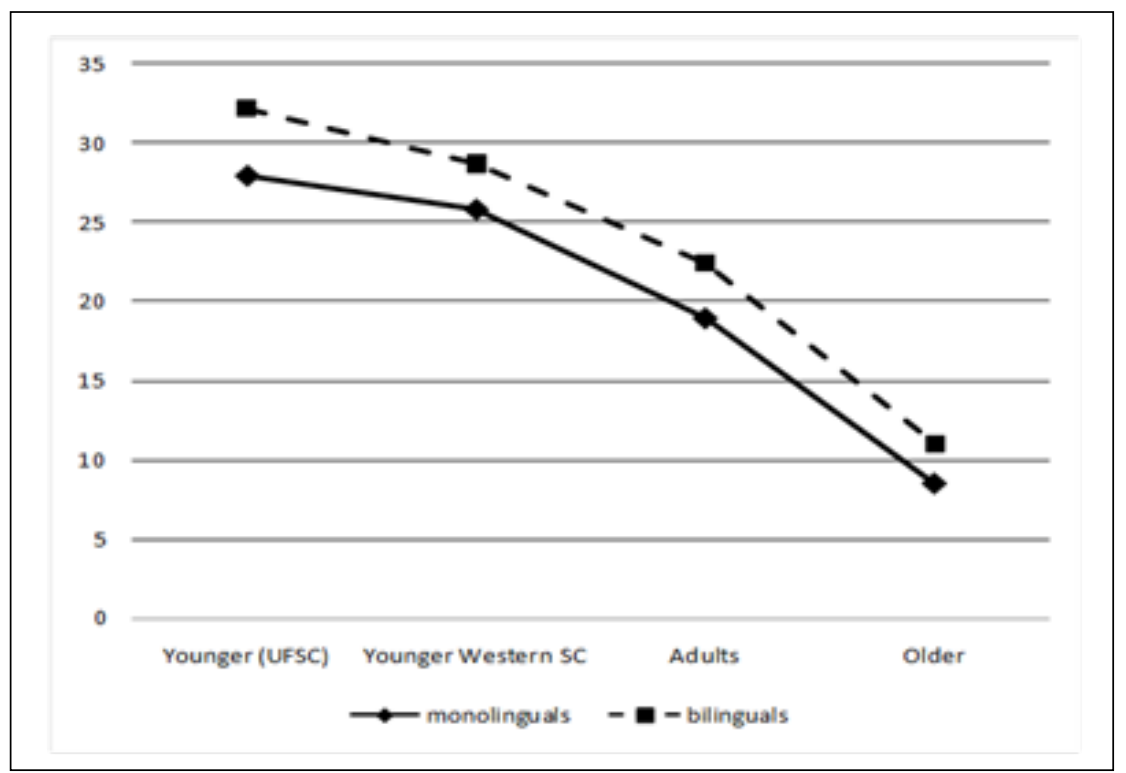

Although this advantage was not statistically significant, it suggests that early and late bilingualism attenuates agerelated losses of verbal working memory because bilinguals obtained better results.

Nevertheless, taking into account the Brazilian context, this type of research is in its infancy. Further empirical studies will be required for fully understanding the effects of bilingualism on cognitive functions. In the case of this study and three other studies already conducted in Brazil with early bilinguals (BILLIG, 2009; PINTO, 2009; RODRIGUES, 2013) in which lifelong bilinguals' performance did not show statically significant differences compared to monolinguals, 
these results made us question whether a delay in age-related decline depends on the bilinguals' contexts. As Paradis (2004) explains, despite the fact that bilinguals share the experience of using two or more languages, there are many types of bilinguals who differ in a number of aspects and cannot be considered a homogenous group. As previously mentioned, the early bilinguals investigated in this research differ from those commonly investigated: they were not educated in either language and had low levels of formal education, particularly the older adult groups. Considering these aspects, levels of cognitive enhancement seem also to depend on other factors, such as the type of bilingualism and level of schooling.

\section{Conclusions}

In summary, the results of the present study revealed a statistically significant age-related decrease in inhibitory control functions; that is, older monolingual and bilingual groups showed increased reaction time and higher Simon effect compared to the younger participants. This means that the ability to inhibit irrelevant information decreases with aging. With regard to language groups, the results did not show statistically significant differences between monolinguals and early bilinguals. However, in the inhibitory control task, a tendency for bilingual advantage can be seen in the magnitude of the Simon effect, which was smaller for the older bilingual group than for the older monolingual group. Furthermore, early bilinguals were more accurate than monolinguals on incongruent trials. Late bilinguals were statistically faster than their monolingual peers on incongruent trials, which can be interpreted as evidence that bilingualism enhances inhibitory control in those who have acquired a second language in a formal context. With regard to working memory, early and late bilinguals could store, manipulate, and repeat words more correctly than monolinguals. These results can be taken as evidence that bilingualism, regardless of context and age of acquisition, can benefit inhibitory control and working memory. 


\section{REFERENCES}

ALAIN, C.; WOODS, D. L. Age-related changes in processing auditory stimuli during attention: Evidence for deficits in inhibitory control and sensory memory. Psychology and Aging, v. 14, n. 3, p. 507-519, set. 1999.

ALTENHOFEN, C. V.; FREY, J. Das bresilionische Deitsch unn die deitsche Bresilioner: En Hunsrickisch red fo die sprocherechte. Revista Contingencia, n. 1, p. 39-50, 2006.

BECK, A. T.; STEER, R. A. (1993). Beck depression Inventory. San Antonio: Psychological Corporation, 1993.

BERTOLUCCI, P. H. F. et al. O mini exame do estado mental em uma população geral: impacto da escolaridade. Arquivo de Neuropsiquiatria, v. 52, n. 1, p. 1-7, 1994.

BIALYSTOK, E. Global-local and trail-making tasks by monolingual and bilingual children: Beyond inhibition. Development Psychology, v. 46, n. 1, p. 93-105, Jan. 2010.

BIALISTOK, E. Cognitive effects of bilingualism: how linguistic experience leads to cognitive change. The International Journal of Bilingual Education and Bilingualism, v. 10, n. 3, p. 210-223, 2007. BIALISTOK, E.; CRAIK, F. I. M. \& FREEDMAN, M. Bilingualism as a protection against the onset of symptoms of dementia. Neuropsychologia, v. 45, n. 2, p. 459-464, 2007.

BIALISTOK, E.; MARTIN, M. M.; VISWANATHAN, M. Bilingualism across the lifespan: The rise and fall of inhibitory control. International Journal of Bilingualism, v. 9, n. 1, p. 103-119, Mar. 2005.

BIALISTOK, E.; CRAIK, F. I. M. Lifespan cognition: Mechanisms of change. Oxford: Oxford University Press, 2006

BIALISTOK, E. Effect of bilingualism and computer video game experience on the Simon task. Canadian Journal of Experimental Psychology, v. 60, n. 1, p. 68-79, Mar. 2006.

BIALISTOK, E.; CRAIK, F. I. M; KLEIN, R.; VISWANATHAN, $\mathrm{M}$. Bilingualism, aging and cognitive control: Evidence from Simon task. Psychology and aging, v. 19, n. 2, p. 290-303, Jun. 2004. BILLIG, J. D. Bilinguismo e envelhecimento: Efeitos no controle cognitivo. 2009. 119 f. Dissertação (Mestrado em Letras), Universidade Federal do Rio Grande do Sul. 
BRAUN, F. K. Memórias do povo alemão no Rio Grande do Sul. Nova Petrópolis, RG: Editora Amsrad, 2010.

BUCKNER, E.; HEAD, D.; LUSTIG, C. Brain changes in aging: a life span perspective. In BIALYSTOK, E.; CRAIK, F. (Ogs.). Lifespan cognition: Mechanisms of change. Oxford: Oxford University Press, 2006. p. 27-42.

BUTLER, K. M.; ZACKS, R. T. Age deficits in the control of prepotent responses: Evidence from inhibitory decline. Psychology and Aging, v. 21, n. 3, p. 638-643, Set. 2006.

CRAIK, F. I. M.;SALTHOUSE, T. A. Handbook of aging and cognition. 2. ed. Hillsdale, N.J.: Lawrence Erlbaum Associates, 2000.

CONWAY, A. R. A.; JARROLD, C.; KANE, M. J.; MIYAKE, A.; TOWSE, J. N. Variation in working memory: An introduction. In . (Orgs.). Variation in working memory. Oxford:

Oxford University Press, 2008. p. 3-17.

COSTA, A.; HERNÁNDEZ, M.; SEBASTIÁN-GALLES, N. Bilingualism aids conflict resolution: Evidence from the ANT task. Cognition, v. 106, n. 1, p. 59-86, Jan. 2008.

DANIELS, K.; TOTH, J.; JACOBY, L. The aging of executive functions. In BIALYSTOK, E.; CRAIK, F. (Ogs.). Lifespan cognition: Mechanisms of schange. Oxford: Oxford University Press, 2006. p. 96-111.

ENGLE, R. W. Working memory capacity as executive attention. Current Directions in Psychological Science, v. 11, n. 1, p. 19-23, Fev. 2002.

FOLSTEIN, M. F.; FOLSTEIN, S. E.; McHUGH, P. R. "Minimental state." A practical method for grading the cognitive state patients for the clinician. Journal of Psychiatric Research, $\mathrm{v}$. 12, n. 3, p. 189-198, Nov. 1975.

GORESTEIN, C.; ANDRADE, L. Validation of a Portuguese version of the Beck Depression Inventory and State-trait Anxiety Inventory in Brazilian subjects. Revista de Psiquiatria Clínica, v. 29, n. 4, p. 453-457, Abr. 1996.

HOFER, S. M.; ALWIN, D. F. Handbook of cognitive aging: Interdisciplinary perspectives. Thousand Oaks, CA: Sage Publications, 2008. 
LUSZCZ, M. A. ; LANE, A. P. Executive function in cognitive, neuropsychological, and clinic aging. In HOFER, S. M.; ALWIN, D. F. (Org.). Handbook of Cognitive Aging: Interdisciplinary Perspectives. Thousand Oaks, CA: Sage Publications, 2008. p. 151-167.

MENDONÇA, T. M. S. Avaliação prospectiva da qualidade de vida relacionada à saúde em idosos com fratura do quadril por meio de um instrumento genérico - the medical outcome study 36-item short-form health survey (sf-36). 2006. 119f. Dissertação (Mestrado em Ciências da Saúde) - Faculdade de Medicina, Universidade Federal de Uberlândia.

MIYAKE, A.; FRIEDMAN, N. P.; EMERSON, M. J.; WITZKI, A. H.; HOWERTER, A.; WAGER, T. D. The unity and diversity of executive functions and their contributions to Complex 'frontal lobe" tasks: A latent variable analysis. Cognitive Psychology, v. 41, n. 1, p. 49-100, Ago. 2000.

PARADIS, M. A Neurolinguistic theory of bilingualism. Amsterdam: John Benjamins, 2004.

PARK, D. C; SCHWARZ, N. Cognitive aging: A Prime. Philadelphia: Psychology Press, 2000.

PARK, D. C. The basic mechanisms accounting for age-related decline in cognitive function. In PARK, D. C; SCHWARZ, N. (Org.). Cognitive Aging: A Prime. Philadelphia: Psychology Press, 2000. p. 3-21.

PARK, D. C.; LAUTENSCHLAGER, G.; HEDDEN, T.; DAVIDSON, N. S.; SMITH, A. D.; SMITH, P. K. Models of visuospatial and verbal memory across the adult life span. Psychology and Aging, v. 17, n. 2, p. 299-320, Jun. 2002.

PINTO, L. M. C. A relação entre o bilinguismo e as funções executivas no envelhecimento. 2009. 125 f. Dissertação (Mestrado em Letras), Centro Universitário Ritter dos Reis.

REED, S. K. Cognition: Theory and applications. 7 ed. Belmont, CA: Thomson Wadsworth, 2007.

RODRIGUES, L. R. Cognitive differences between monolinguals and multilinguals: executive functions boosted by codeswitching? 2013. 92 f. Dissertação (Mestrado em Letras), Universidade Católica de Pelotas. 
SALTHOUSE, T. A.; MEINZ, E. J. Aging, inhibition, working memory, and speed. Journal of Gerontology: Psychological Science, v. 50, n. 6, p. 297-306, Nov. 1995.

SALVATIERRA, J. L. The effects of bilingualism and aging on inhibitory control. 2007, 56 f. Tese (Doutorado em Filosofia), Florida Atlantic University.

SALVATIERRA, J. L.; ROSSELLI, M. The effect of bilingualism and age on inhibitory control. International Journal of Bilingualism, v. 15, n. 1, p. 26-37, Set. 2010.

VALENZUELA, M. J. Brain reserve and the prevention of dementia. Current Opinion in Psychiatry, v. 21, n. 3, p. 296-302, Mai. 2008.

VAN DER LUBBE, R. H. J.; VERLEGE, R. Aging and the Simon task. Psychophysiology, v. 39, n. 1, p. 100-110, Jan. 2002.

ZELLNER, M.; BAUML, K. Inhibitory deficits in older adults: List-method directed forgetting. Journal of Experimental Psychology: Learning, Memory, and Cognition, v. 32, n. 2, p. 290300, Mar. 2006. 


\section{Resumo}

Efeitos do bilinguismo no controle inibitório e memória de trabalho: Um estudo com bilíngues de infância e bilíngues tardios

Muitos estudos demonstram que as funções cognitivas mudam com a idade. Estudos recentes fornecem evidências de que o bilinguismo pode atenuar alguns efeitos negativos do envelhecimento e atuar como uma proteção às funções cognitivas ao longo da vida (Bialystok, Craik, Klein $\mathcal{E}$ Viswanathan, 2004; Salvatierra, 2007). O presente estudo compara o desempenho de bilingues precoces (português brasileiro/hunsrückisch), bilingues tardios (português brasileiro/inglês) e monolingues (português brasileiro) em tarefas de controle executivo e memória de trabalho. Para tanto, 104 participantes realizaram uma tarefa de controle executivo (Simon) $e$ uma tarefa de memória de trabalho (Alpha Span). As análises estatísticas demonstraram perdas cognitivas significativas relacionadas à idade, uma vez que adultos jovens foram melhores que os idosos nas tarefas de controle inibitório e memória de trabalho. Além disso, bilingues de infância apresentaram maior eficiência nos processos inibitórios e pontuaram mais que os monolíngues na tarefa de memória de trabalho. Os resultados confirmaram que bilingues tardios foram significativamente melhores que os monolingues em controle inibitório. Estes resultados são interpretados como evidência de que o bilinguismo, independentemente do contexto e da idade de aquisição, pode trazer beneficios ao controle inibitório e à memória de trabalho.

Palavras-chave: bilinguismo, envelhecimento, controle inibitório, memória de trabalho 